\title{
FIELD EVALUATION AND CROP CONDITIONS RELATED TO SUGAR CANE MECHANICAL HARVESTING
}

\author{
ABDEL MAWLA H. A. ${ }^{1}$, E. M. ARIF ${ }^{2}$, B. EL-DIN HEMAYDA ${ }^{2}$ \\ and M. E. MOHAMED ${ }^{2}$
}

1. Agric. Eng. Dep., Fac. of Agric., AL-Azhar U. Assiut.

2. Agric. Eng. Res. Institute, $A R C$.

(Manuscript received 11 January 2014)

\begin{abstract}
This research with aims to evaluate the performances of local manufacturing sugar cane harvesting machine in field as responses+ to crop conditions. Field conditions determined to have important influence on the performance of a mechanical harvesting were: The inter row spacing of sugar cane. The sugar cane furrow depth. The transverse ridges intervals. The sugar cane field established before planted and continues in the field for 5 years. The results of the field and crop conditions show that in the field conditions of inter row spacing ranged from 0.85 to $0.9 \mathrm{~m}$. Furrow depths ranged from 12 to $21 \mathrm{~cm}$ and transverse ridges intervals ranged from 12 to $20 \mathrm{~cm}$. and the crop conditions of the average crop density was 10.85 mealable stalks $/ \mathrm{m}^{2}$. For lodging condition the percent of erect crop was $66 \%$ in the case of newly planted crop reduced to $35 \%$ in case of the final Raton. Percent lodged was $26 \%$ in case of the newly planted crop increased to $37 \%$ in case of the final Raton. The percent of recumbent crop increased from $8 \%$ in the new crop to $28 \%$ in the final Raton. The average mealable stalk dimensions were $182.2 \mathrm{~cm}$ for length $2.46 \mathrm{~cm}$ diameter and $0.824 \mathrm{~kg}$ wight. Cane material mechanical properties, resulted that the average internodes of $500 \mathrm{~N}$ for chair stress, $4258 \mathrm{~N}$ compression strength and $863.2 \mathrm{~N}$ for bending moment.
\end{abstract}

\section{INTRDODUCTION}

Mechanical harvesting of sugarcane is largely affected by field conditions and crop properties. Field conditions that set by certain agricultural practices such as inter-row spaces and furrow depths should be proportional to the dimensions of the machine axes and ground clearance. Certain sugarcane harvester designs have limited abilities for harvesting lodged crop. Cane stalk density per unit area may largely affect the production of malleable cane. Mechanical properties such as stalk hardness and shear strength may affect the performance of the cutting edge of the cane harvester.

Braunack et al. (2006), stated that field trials were conducted for a period of 5 years at two locations in north Queeisland and with four sugarcane varieties to quantify the effect of harvest traffic on soil physical properties and sugarcane growth. 
Stalk numbers and heights and yield indicated little difference with respect to treatment, but there was a significant varietal difference. The varieties Q138 and Q124 were taller and had greater yield than Q117 and Q115. The effect of traffic appeared to be cumulative, as the degree of soil compactness and bulk density increased, with treatment differences becoming significant with each additional year of traffic. Traffic over the row resulted in a yield loss compared with traffic near-therow and down the inter-row. Smith and Hamel (1999) mentioned that the stalk of sugarcane consist of series of nodes, where leaf sheaths attach, and internodes, which form the bulk of the sucrose storage tissue. Both nodes and internodes are usually solid. Srivastava et al. (1993) indicated that the plant consists of solid material, liquid and air-filled spaces. The fiber cells that are arranged in bundle spirals called micro fibrils provide the strength. Salassi Michael E. and Lonnie P. Champagne (1996) stated many factors which influence the actual costs of a sugarcane harvesting and hauling system imply that these costs can vary from one farm situation to another. As a result, sugarcane producers who are considering alternative harvesting systems should evaluate the estimated costs of each system for their particular farm situation. Arvidsson and $\mathrm{Ha}^{\circ}$ kansson (1991). Demonstrated that agreement between measured yield loss and predicted yield loss was reasonable. This is the first attempt to provide the Australian sugar industry with a tool to assess the yield loss due to harvesting traffic and the economic cost of that loss. The model has the potential to provide, with further development, an indication to growers as to the benefit of restricting traffic to the inter-row area, restricting the number of passes by haul outs, harvesting under drier soil conditions and using high flotation haul out equipment. This should aid in more informed management decisions with respect to harvesting equipment or to the consequences of harvesting under adverse soil conditions.

Wiedenfeld (2009) found that the soil organic matter content after three years was increased by green harvesting compared to burning prior to harvest. Harvesting green compared to burning caused a $20 \%$ reduction in yield in the $2^{\text {nd }}$ Raton and a slight reduction in crop growth but an $8 \%$ increase in sucrose content in the $3^{\text {rd }}$ Raton crop. While the effects due to green harvesting on soil properties and crop growth were relatively minor, the residue remaining on the soil presents considerable challenges in cultivation, weed control and irrigation. Differences in sugarcane yields due to harvesting green vs pre harvest burning have been inconsistent. Bianchinia and Magalna(2008) coulter types have not performed well when working in areas with large amounts of crop residue. The performance of these coulters is influenced by several characteristics of the disc itself (diameter, shape, thickness, angle, and degree of sharpening), of the soil (moisture content, texture, and resistance to penetration), 
and of the crop residue (plant species, plant maturation stage, deposition time, moisture, and concentration of the material). The relationships among the soil conditions created by conservation tillage, the presence of crop residues on the soil surface, and the operation of the cutting discs are not yet well understood. When the soil is moist or loose, the cutting disc tends to push the crop residue into the soil without cutting it. Garside et al. (2005), stated that the growers expressed concerns regarding productivity declines, harvesting difficulties and the need to change cropping practices and these concerns slowed the transition from a burnt cane system to a green cane trash blanket GCTB. However, there is now little doubt that GCTB is well established in the industry and benefits are accruing, both in terms of productivity and sustainability, as growers become more skilled in managing green cane. Essentially, the Sugar Yield Decline Joint Venture (SYDJV) program is now dedicating much of its time to developing such a cropping system. The system envisaged is based around row spacings compatible with wheel spacings of the heaviest equipment (harvester and haulouts) to avoid stool damage and minimize compaction near the cane row.

Bosoi et al. (1991), mentioned that the cutting resistance depends upon the physical and mechanical properties of the stalk and the thickness of the cutting edge and is perpendicular to the cutting edge. El-Nakib et al. (1996), studied some physical and mechanical properties of sugarcane mainly: stalk dimensions, mass, number of buds, curvature, hardness and coefficient of friction and their relation to mechanization. They found that the average length and diameter of the sugarcane stalk for the Egyptian variety C9 were $178 \mathrm{~cm}$ and $2.3 \mathrm{~cm}$ respectively, the average stalk mass was $0.794 \mathrm{~kg}$, the average stalk radius of curvature was $560 \mathrm{~cm}$. The cane stalk hardness was $775 \mathrm{cN}$ and the average coefficients of friction were 8.8, 7.6 and 8.9 degrees with wood, rubber and steel. Chen Chao Jun et al .(2012), stated that the experiment was conducted with the traditional manual harvesting and mechanical harvesting of sugarcane, to compare the effects of different harvesting method on the sugarcane stubble quality and the growth of Raton. The experimental results are as follows. (i) The stubble height and breaking stubble rate of mechanical harvesting was significantly higher than manual harvesting, the stubble height of lodging species and difficult defoliation species increased in mechanical harvesting condition. Varieties with higher levels of fiber had lower rate of broken stubble, (ii) The effects of mechanical harvesting on germination of next year Raton were quite different due to different varieties, indicating that the better perennial species have less impact than the poor perennial species. (iii) Compared with manual harvesting, mechanical harvesting had slightly higher plant height and single-stem weight and less effective stems number, 
the difference of cane yield was not significant, but sucrose content increased $0.53 \%$. (iv) Mechanical harvesting combining with leaves crushing could reduce the impact on the germination of Raton, improve the single-stem weight and increase the effective number of stems. Neves et al. (2006), observed that in this work the performance of a sugar cane chopped harvester was analyzed when fed with two sugar cane mass flows, measuring the invisible losses, which are impossible to measure in the field, harvester sugar cane cleaning efficiency and air velocity on extractors exit. The trial was done under controlled conditions at Copersucar Technology Center in January 2000. The results showed that the flow of sugar cane through the harvester doesn't influence the magnitudes of total invisible losses and raw material cleaning efficiency. The mean air velocity on the primary extractors exit was $12.0 \mathrm{~m} \mathrm{~s}^{-1}$, and $9.2 \mathrm{~m} \mathrm{~s}^{-1}$ on the secondary extractor, with a coefficient of variation of $21 \%$, indicating that the poor cleaning performance of the harvester could be related to air velocity difference inside the extractor. Analyzing the data collected in the trials, it was possible to conclude that invisible losses in sugar cane harvester were $10 \%$ and the cleaning efficiency was $87 \%$. Drees (2005) found that the cutting resistance changed from $1272 \mathrm{~N}$ to $1140 \mathrm{~N}$ through the stalk bottom (bud No. 1 to No.6) and declined from 1116 to $936 \mathrm{~N}$ at stalk middle (bud No.6 to 9) at the top of stalk, cutting resistance declined down to reach $768 \mathrm{~N}$. Minimum cutting resistance was recorded at upper part of stalk. The ratio of force applied for cutting to the resistance ranged between 2.56 to 2.07 when the diameter of sugar cane stalk ranged from 2.1 to $3.05 \mathrm{~cm}$.

Bakker (1999) mentioned that chopped cane harvester cut, or chop, cane into pieces of 3 to 5 internodes and load these into suitable transport units. Crop dividers raise tangled cane from the ground, separating it from adjoining rows and guiding it towards a topper. The tops are removed and discharged clear of the harvester. Prior to cutting, the cane is pushed forward in the travel direction of the machine by a knockdown roller or bar, causing the cane to be fed into the machine in an appropriate position. Fuelling (1999) stated that Chopper harvesters cut burnt or unburned cane into billets of lengths approximately $200 \mathrm{~mm}$ in length. As with whole stalk harvester, the stems are gathered and cut at the base, topped and drawn into the machine butt end first. The cane is then cut into billets either by meshing rollers or by a rotating knife. The cane is then cleaned where the trash is extracted out the primary extractor. The billeted cane is conveyed up and out of the secondary extractor into a separate trailer. 


\section{MATERIALS AND METHODS}

Experiments were conducted at the sugarcane farms of Mallawy Research station to measure field and crop conditions. Measurements of the field conditions were repeated 10 times and taken from cane fields belongs to the Mallawy Research Stations and other fields belongs to small cane farmers. Field and crop conditions that have major effect on mechanical harvesting were specified as follow.

1- Field conditions related to agricultural practices:

- Inter-row spacing

- Transverse ridges interval distance

- Furrow depths and furrow profile

2- Crop conditions:

a- Cane standings per ful. Crop density was measured by counting malleable cane stalks grow in one meter along furrow. The density was then computed by knowing cane crop row spaces.

b- Crop lodging according to, cane lodging classified into, erect cane, lodged cane and recumbent cane Fig (1). The same classification was considered to identify the lodging type of the experimental sugar cane field as follow:

- Erect cane (up to $\geq 60^{\circ}$ )

- Lodged $\left(60^{\circ}\right.$ to $\left.30^{\circ}\right)$

- Recumbent $\left(\leq 30^{\circ}\right)$

- Group bundled cane

Adequate number of replicates were taken from several fields of the Mallawy Research Station as well as fields belongs to sugarcane farmers within the area. Fig 1 show the identification of the erect, lodged and recumbent cane.

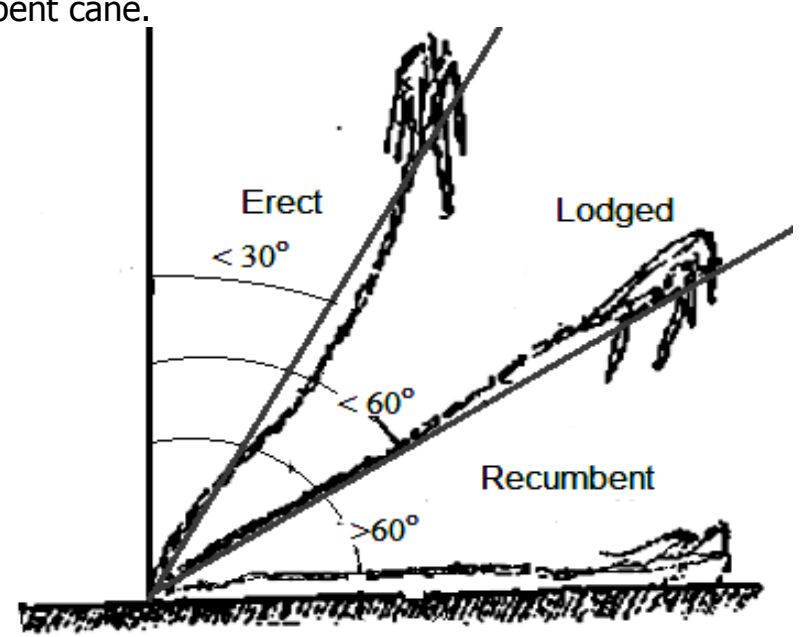

Fig 1 identification of cane lodging level. Ripolic.C.L.G.Mialhe (1983) 
3- Sugar cane stalk material properties that affect mechanical harvesting were measured from several fields in Mallawy Research Station and sugarcane farmers that all grow cane variety C9.

- Stalk length

- Stalk diameter

- Stalk weight

4- Sugarcane stalk material properties that affect mechanical harvesting were measured in the Laboratory of Material Science of the College of Engineering, Cairo University. The properties measured included: Cane material hardness (inter-node hardness)

- Tensile strength

- Compression strength

- Bending moment

\section{RESULTS AND DISCUSSION}

\section{Field conditions related to agricultural practices}

Field conditions that have the most important effect on mechanical harvesting were, inter-row spacing, transverse ridges intervals and furrow depths. Inter row spacing may have great affect on the efficiency of the sugarcane harvesting machine. Inter row spacing should match the dimensions of the harvesting machine axle or the distance between the harvester wheel. Narrow inter row spacing mean that the machine wheels will not be aligned along the furrow bottom that reduces the control on the machine and cutting depth. Excessive transverse ridges that established to control the irrigation water may cause abstractions to the machine forward advancing. At these ridges excessive losses of harvested cane may be expected. The ridges also case interruption to the smooth motion of the machine that may affect the harvester efficiency. Deep furrow may cause problems due to the limited ground clearance of the harvester. Deep furrows also cause interruption while turning at the heads of the field. Other problems may also be expected due to loosing the control on cutting height because of deep furrows. Table (1) shows the data according to field measurements collected for the first, second, third and fourth Raton's sugar cane.

This Table shows that furrow widths that represent inter row spacing ranged from 85 to $90 \mathrm{~cm}$. Furrow depths ranged from 12 to $21 \mathrm{~cm}$. Actually furrow seems to be more deep in case of newly planted crop and furrow depths reduces gradually to be about $12 \mathrm{~cm}$ in case of the final Raton. Transverse ridges measurements show 
the range of $12 \mathrm{~m}$ to about $20 \mathrm{~m}$ in all the fields of the experiments. Excessive ridges in the fields from which the data were collected, may be because of poor leveling of the field's surface. Farmers have to make short distances between transverse ridges to control irrigation water.

Table 1. Average values of the field conditions most affected mechanical harvesting

\begin{tabular}{|l|c|c|c|c|c|c|}
\hline Field condition & $\begin{array}{c}\text { New } \\
\text { Crop }\end{array}$ & $\begin{array}{c}\text { First } \\
\text { Raton }\end{array}$ & $\begin{array}{c}\text { Second } \\
\text { Raton }\end{array}$ & $\begin{array}{c}\text { Third } \\
\text { Raton }\end{array}$ & $\begin{array}{c}\text { Fourth } \\
\text { Raton }\end{array}$ & Mean \\
\hline Inter-Row spacing, mean, cm & 88 & 85 & 87 & 85 & 90 & 87 \\
\hline Furrow Depths, mean, cm & 21 & 18 & 14 & 12 & 12 & 15.4 \\
\hline Transverse ridges interval, range, m & $12-18$ & $13-18$ & $15-20$ & $15-22$ & $12-19$ & \\
\hline
\end{tabular}

\section{Crop conditions:}

The most important crop conditions that affect mechanical harvester of sugarcane are crop density and crop lodging. Actually all the sugarcane crop properties affect mechanical harvesting but there only two crop properties may have the direct influence on the machine performance, losses and cane quality. Crop density widely affects all other crop properties such as, stalk dimensions, lodging, crop stability, malleable cane, stalk trash, ratio of green top to stalk weight and many others properties that may have direct influence on mechanical harvesting. Higher density may mean weak trash crop, poor stability of the crop against mechanical handing and lower ratio of malleable cane to the hole population of the crop. Cane lading is the crop conditions may have the maximum influence on mechanical harvesting. Cane lodging reduces the efficiency of the base cutter mechanism, reduce the efficiency of handling mechanism, increases losses and increase harvesting damage. Cane lodging may be classified according to the angle of tilting cane stalks with respect to vertical positions. If we consider the angle between the straight lines passes through the stalk base through the stalk green top with respect to the ground surface consequently cane crop may be classified into erect, lodged and recumbent crop according to the indemnification illustrated. Erect cane crop may be identified as cane stalks make $>60^{\circ}$ with respect to ground surface. Lodged cane may be tilted between 60 to $30^{\circ}$ with respect to ground surface. Recumbent cane may make $<30^{\circ}$ with respect to ground surface.

It has been established that the all hole-stalk harvesters mechanical harvesting of recumbent cane is very hard task. Harvesting lodged cane with a whole stalk harvester may accomplish with scarification of machine efficiency and losses. Also windrowing efficiency of the mechanical harvester will be severely affected with cane 
crop lodging. For recumbent crop, the chopper harvester may be the proper machine to be used and the use of whale stalk harvester should be avoided. In some countries agricultural practices may be adjusted to control cane lodging in which deep seed cover wider inter row spaces and lower crop population may conserved. In such countries series programs of plant breading may be followed to obtain cane seed of a crop that resist lodging. Fig (2) shows crop lodging as affected by Crop Raton. Table (2) presents the data of crop density stalk/ $\mathrm{m}^{2}$ and the corresponding crop lodging. For the fields in which the experiments were conducted, crop density ranged from 10.2 to 10.9 of malleable cane stalks $/ \mathrm{m}^{2}$. Crop lodging data presented in the same table show that Raton rank may have larger effect on cane crop lodging. The percent of erect cane decreased from $60 \%$ in case of the newly planted field to be less than $50 \%$ in case of the $4^{\text {th }}$ Raton. Lodged cane seems to slightly increase also with the Raton rank. The percent of recumbent crop showed clease increase with Raton rank, where present recumbent increased from less than $10 \%$ in case of the newly planted crop to be more than $25 \%$ in case of the $3^{\text {rd }}$ Raton.

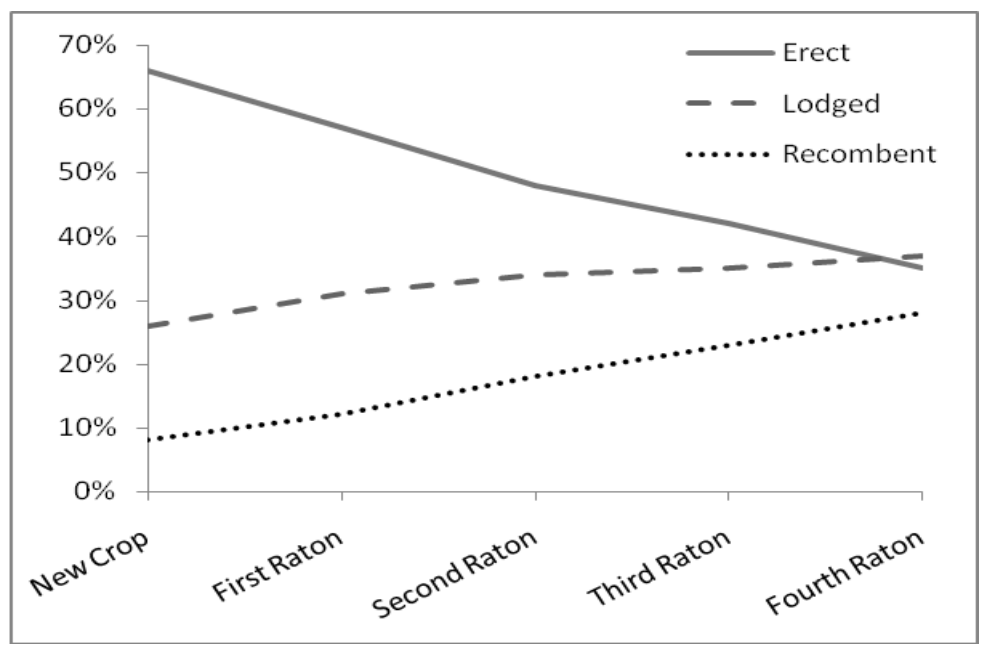

Fig 2. Crop lodging as affected by Crop Raton

Table 2. Average values of the field conditions, crop density and crop lodging most affected mechanical harvesting.

\begin{tabular}{|c|c|c|c|c|}
\hline \multirow{2}{*}{ Crop conditions } & Crop density & \multicolumn{3}{|c|}{ Crop lodging } \\
\cline { 2 - 5 } & Stalk/m & $\begin{array}{c}\text { Erect } \\
\left(>60^{\circ}\right)\end{array}$ & $\begin{array}{c}\text { Lodged } \\
\left(60^{\circ} \text { to } 30^{\circ}\right)\end{array}$ & $\begin{array}{c}\text { Recumbent } \\
\left(<30^{\circ}\right)\end{array}$ \\
\hline New Crop & 10.4 & $66 \%$ & $26 \%$ & $8 \%$ \\
\hline First Raton & 10.9 & $57 \%$ & $31 \%$ & $12 \%$ \\
\hline Second Raton & 10.5 & $48 \%$ & $34 \%$ & $18 \%$ \\
\hline Third Raton & 10.8 & $42 \%$ & $35 \%$ & $23 \%$ \\
\hline Fourth Raton & 10.2 & $35 \%$ & $37 \%$ & $28 \%$ \\
\hline Mean & 10.56 & 49.6 & 32.6 & 17.8 \\
\hline
\end{tabular}




\section{Evaluation of cane properties related to mechanical harvesting: Crop dimensions:}

Cane stalk dimensions represented in stalk diameter, stalk length and stalk weight may have important effect on the performance of sugar cane mechanical harvesting. The properly established sugar cane field supposed to have strongly growing crop in which the malleable cane stalks represent high ratio of the total population of the field. Healthy crop may mean that erect strong stalks are of maximum ratio. Stalk diameter may be the most important criteria that determine the sugar cane crop condition from the point of view of malleability. Strong stalks of larger diameter may mean that the crop is more reliable for mechanical harvesting.

The larger the crop stalk diameter, the lower the crop lodging probability and the higher the efficiency of the mechanical harvester. Stalk length is also an effective factor that may determine the efficiency of the handling and windrowing mechanism of the mechanical harvester. The higher the length of sugar cane stalks the lower the efficiency of the handling and windrowing mechanism of the sugar cane mechanical harvester, especially for the small and tractor mounted machines. Sugar cane stalk weight is the resultant of its diameter and length. Stalk weight and the green top weight may also be effective because it determines the location of the center of gravity of the stalk. The handling mechanism efficiency may be determined by the force of holding and the location of the center of gravity of the stalk. Complex handling mechanism may not be possible to be constricted to the small harvester. Simple one should be provided considering that criteria as much as possible. The data of Table (3) show the dala of crop dimension. Stalk length ranged from 172 to $189 \mathrm{~cm}$ depends on the Raton. Actually the measured length is that of the clean cane stalk with green top cut. Cane stalk diameter was up to $2.7 \mathrm{~cm}$ and cane stalk weight was also up to $0.86 \mathrm{~kg}$. At should be clear that the above represent the stalk dimensions and weight of the clean cane stalk considering only the malleable cane stalks. The samples collected from a uniform growing area of the sugar cane field.

Table 3. Average values of cane stalk dimensions affected mechanical harvesting.

\begin{tabular}{|l|c|c|c|c|c|c|}
\hline \multicolumn{1}{|c|}{ Cane stalk properties } & $\begin{array}{c}\text { New } \\
\text { Crop }\end{array}$ & First Raton & $\begin{array}{c}\text { Second } \\
\text { Raton }\end{array}$ & $\begin{array}{c}\text { Third } \\
\text { Raton }\end{array}$ & $\begin{array}{c}\text { Fourth } \\
\text { Raton }\end{array}$ & Mean \\
\hline Clean stalk length, cm & 172 & 178 & 189 & 188 & 184 & 182.2 \\
\hline Stalk diameter cm & 2.2 & 2.4 & 2.4 & 2.6 & 2.7 & 2.46 \\
\hline Stalk weight, kg & 0.79 & 0.83 & 0.86 & 0.81 & 0.83 & 0.824 \\
\hline
\end{tabular}




\section{Crop material properties:}

Cane stalk material properties are necessary to be measured. The cane stalk materials could be measured were, cane material hardness, compression strength and bending moment. Cane stalk material surface hardness is required to explain the behavior of the base cutter of the sugar cane harvester. Cane material surface hardness may vary according to the crop age.

In Egypt, sugar cane should be harvested at a full year age. In very common cases harvesting some fields may be delayed for some reason or another that result more hard surface of the cane stalk that may have influence on the performance of the base cutter of the mechanical harvester. On the other hand, cane surface hardness may obviously vary according to the cane variety. Strength of the sugar cane material may refer to the percent of fibers in the components of the cane stalk. Compression strength may be the property reflects the resistance to the aggressive contact against the mechanical parts of the machine mechanisms. Compression strength may explain the ability of the cane stalks to stand against the action that makes the stalk kinked a side and lost by the action of base cutter of windrowing mechanism. Bending moment was one of the important tests applied to the sugarcane stalk material. Bending moment explains the behavior and type of losses. Bending moment of the cane stalk material reflects the behavior of the stalk toward two types of properties that are brittleness and kinking. Cane stalk material properties are necessary to explain the behavior of the cane stalk in contact with the functional mechanisms of the mechanical harvester. These properties also explain the types and forms of losses and damage.

Table (4) show the data according to the measurements done at the material laboratory of the college of engineers. Cairo University. The table show that surface hardness at the internodes was $325 \mathrm{~N}$ of samples taken from the newly planted crop, 452 for the $1^{\text {st }}$ Raton , 515 for the $2^{\text {nd }}$ Raton , 601 for the $3^{\text {rd }}$ Raton and $607 \mathrm{~N}$ for the $4^{\text {th }}$ Raton. The data show that for the one year age sugar cane stalk, hardness increase directly with Raton rank. Compression strength recorded for the newly planted crop was $4180 \mathrm{~N}$ increased to become $4340 \mathrm{~N}$ incase of the $4^{\text {th }}$ Raton. This property also show direct increase with the crop Raton rank. Break bending moment was $840 \mathrm{~N}$ for the newly Planted crop increased to be up to $886 \mathrm{~N}$ in case of the $4^{\text {th }}$ Raton. Now all material measurements show direct increase with Raton rank that approve the mechanical harvesting become harder. 
Table 4. Average values of some cane stalk properties affected mechanical harvesting.

\begin{tabular}{|l|c|c|c|c|c|c|}
\hline \multicolumn{1}{|c|}{ Cane stalk properties } & $\begin{array}{c}\text { New } \\
\text { Crop }\end{array}$ & $\begin{array}{c}\text { First } \\
\text { Raton }\end{array}$ & $\begin{array}{c}\text { Second } \\
\text { Raton }\end{array}$ & $\begin{array}{c}\text { Third } \\
\text { Raton }\end{array}$ & $\begin{array}{c}\text { Fourth } \\
\text { Raton }\end{array}$ & Mean \\
\hline Inter- node hardness, N & 325 & 452 & 515 & 601 & 607 & 500 \\
\hline Compression strength, N & 4180 & 4200 & 4260 & 4310 & 4340 & 4258 \\
\hline $\begin{array}{l}\text { Bending moment } \\
\text { (breaking load, N) }\end{array}$ & 840 & 855 & 865 & 870 & 886 & 863.2 \\
\hline
\end{tabular}

\section{CONCLUSION}

The principle objective of the current research was to intensively study the field and crop conditions that have the most important influence on sugar cane mechanical harvesting. The following points may be concluded from the results of the article:

I - Field conditions determined to have important influence on the performance of a mechanical harvesting. Inter row spacing of sugar cane which expected to affect the motion of any mechanical harvester. This condition also may have direct effect on several crop properties and crop production. Sugar cane furrow depth that may have important influence on the motion of the mechanical harvester. Transverse ridges intervals. The transverse ridges are from intensive transverse ridges in case of the poor leveling of the field surface. All these condones related established to control irrigation water. The farmers have to the operation of field dividing after plowing and the intensity of any of these conditions related to the irrigation system applied in the field. The conditions of field surface on which the mechanical harvester move expected to largely influence the performance of the machine. Machine productivity efficiency, crop losses and mechanical damage may be affected by these conditions. The above conditions may considerably very with the rank of the crop Raton. The sugar cane field established before planted and continues in the field for 4 to 5 years, the above mentioned conditions may stay the same until the crop change after $5 y e a r s$ except for furrow depth which may be change from crop to another according to the manner followed by the farmer while performing hoeing operation.

$\mathbf{\Pi}$ - Crop condition represented in crop density and crop cane stalks that represent the healthy cane stalks, representing lodging were determined as the most effective conditions from the point of view of mechanical harvester. Crop density should largely influence all other crop properties. Mealable the main crop of the sugar cane field may largely affected by cane density. Cane crop lodging may has the absolute influence on mechanical sugar cane harvesting. Sugar cane crop was classified into erect, lodged and recumbent according to the angle of cane stalk 
lodging with respect to the ground surface. The classification was based on the degree of tilting of cane stalks with respect of vertical line passes through the stalk base. Erect cane identified as has stalks tilt up to $30^{\circ}$ with respect to vertical line $60^{\circ}$ with respect to horizontal. Lodged cane tilt with angle reneged from $<60^{\circ}$ to $\geq 30^{\circ}$ with respect to horizontal finally recumbent cane that tilt with angle $<30^{\circ}$ with respect to horizontal Lodging orientation with respect to the harvester advancing will also be considered as effective parameter.

III - Crop material mechanical properties ware also studied because of its influence expected to the performance of the harvester mechanisms. The studied cane material properties were, surface hardness, Compression strength and Bending moment (breaking load, N).

\section{REFERENCES}

1. Bakker, H. 1999. Sugar cane cultivation and management, Harvest and transport. Kluwer Academic/Plenum Publishers.N Y: 219-234

2. Braunack M.V., J. Arvidsson and I. Ha kansson. 2006. Effect of harvest traffic position on soil conditions and sugarcane (Saccharum officinarum) response to environmental Soil \& Tillage Research 89 (2006) 103-121

3. Bianchinia, P., Magalha S.G. 2008. Evaluation of coulters for cutting sugar cane residue in a soil bin. Biosystems engineering 100: $370-375$.

4. Bosoi E.S., O.V. Verniaev,I.I.Smirnov,E.G. Sultan-Shakh. 1991. Theory, Construction and Calculation of Agriculture Machines, Volume Two. A.A. Balkema/Rotterdam: 323-347.

5. Chen ChaoJun, Liang He, He ZhangFei, Mo QingGui, Huang Yan, Kuang WeiSheng, Li TianShao, Lu GuoYing (2012) Effects of mechanical harvesting on sugarcane stubble quality and growth of ratoon. Journal Board of Asian Agricultural Research 2012. 4(6):84-88. 17 ref.

6. Drees, A. M. 2005. "A Study on Mechanization of Sugar Cane Planting " Fabricating a Seedling Preparation Unit and Performance Evaluation of Transplanting Machine for Sugar Cane Crop. . Ph. D. thesis Agric. Mech. Dept. Faculty of Agric., Kafr El-Sheikh. Tanta University.

7. El-Nakib, A. A., A. F. El-Sahrigi and H. A. Abd El-.Mawla. 1996. Physical properties of sugar cane: their relation to mechanization. MSAE exploration of modem tech. In field of Agric. Eng. $4^{\text {th }}$ Conference of Misr Society of Ag. Eng., 28 October 13(4): 63-78 
8. Fuelling, T. 1999. Harvesting quality cane. Proceedings of Australian Society of Sugar Cane Tech.21: 28-32.

9. Garside, A.L., Bell, M.j., Robotham, B.G., Magarey, R.C., and Stirling, G.R., 2005. Managing yield decline in sugarcane cropping systems, Sugar Yield. Decline Joint Venture. Proc. Aust. Soc. Sugar Cane Tech.: 1920-2000.

10. Johan Arvidsson, Inge Håkansson. 1991. A model for estimating crop yield losses caused by soil compaction. Soil Tallage Res. 20, 319-332]

11. Michael E. Salassi and Lonnie P. Champagne. 1996. Estimated costs of soldier and combine sugarcan harvesting systems in Louisiana D.A.E. research report No. 703. Louisiana experiment station, , Louisiana State University.P4-9

12. Neves, J. L. M., A. S. Marchi, A. A. S. Pizzinato, and L. R. Menegasso. 2001. Comparitive testing of a floating and a conventional fixed base cutter. Proceedings of the International Society of Sugar Cane Technologists 24: 257262.

13. Ripolic.C.L.G. Mialhe. 1983. Evaluation somle performance parameters of the combine harvester of sugar cane. Proceeding of ISSCT 1983 1035- 1057.

14. Smith, D.L. and C. Hamel. 1999. Crop yield, Physiology and processes Sugarcane, Spriger-Verlag Berlin Heibelberg: 287-310

15. Srivastava, A. K., C. E. Goering, and R. P. Rohrbach. 1993. Engineering principles of agricultural machines. American Society of Agricultural Engineers, St. Joseph, Michigan, U.S.A.:424-441.

16. Wiedenfeld B. 2009. Effects of green harvesting vs burning on soil properties, growth and yield of sugarcane in South Texas. Journal of the American Society of Sugar Cane Technologists 29: 102-109. 


\section{تقييم للظروف الحقلية والمحصول المتعلقة بالحصاد الآلى لقصب السكر}

حسن عبد الرازق عبد المولى ' ، الأمين محمد عارف' ، بهاء الدين حميده ‘ ، محمد إبر اهيم محمد׳

$$
\text { r - قسم الهندسة الزراعية - كلية الزراعة جامعة الأزهر فرع اسبوط . }
$$

كان الهدف الأصلىمن هذه الدراسه هو تقييم الظروف الحقليه والخواص المحصوليه لقصب السكر المتعلقه و المؤثزه على الحصاد الآلى لذلك المحصول الرئيسى ـ كما تتاولت الدراسه

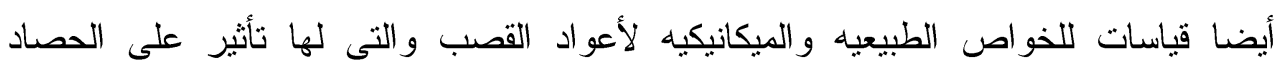

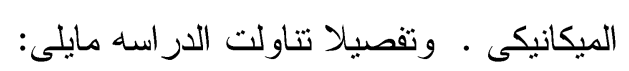

1 - المسافه بين صفوف قصب السكر و التى يتوقع ان تؤثر على حركة التشغيل الميكانيكى. r - عمق الخط والتى تؤثر تأثير ا كبير على حركة التشغيل الميكانيكى .

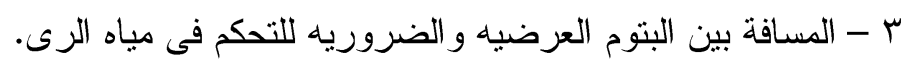
ع- رقم الخلفة وهى تعبر عن عمر سنوات للمحصول الذى يتم حصاده سنويا ويدوم أربع

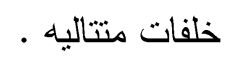

هـ ظروف المحصول من حيث كثافة السيقان القابله للعصير فى المتر المربع وأبعاد ساق

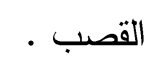

7- الرقاد كخاصيه لها التأثير الأكبر على نجاح الحصاد الميكانيكى ومدى إستقامة النبايات أو

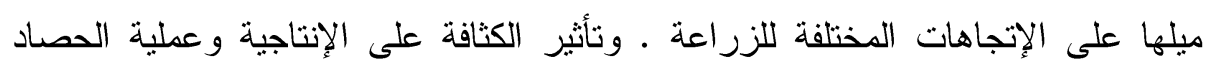

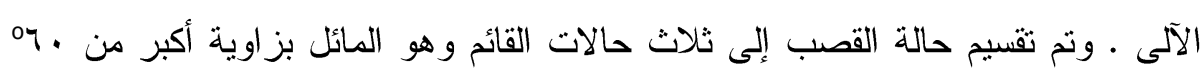

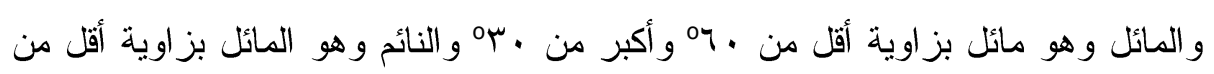

$$
\text { . به على سطح الأرض. }
$$

V- أيضاً نم دراسة بعض الخواص الميكانيكية للمحصول و المؤثرة على الحصاد الآلى منل

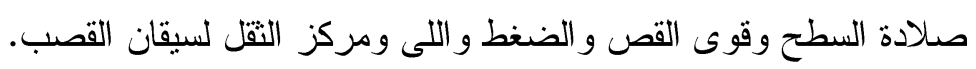

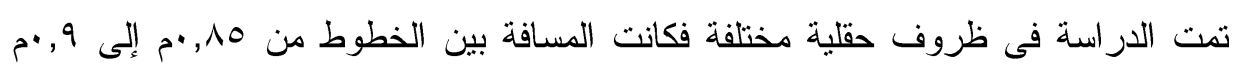

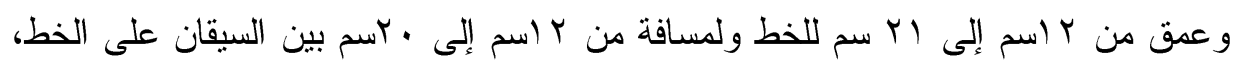

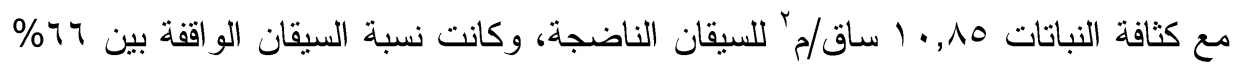

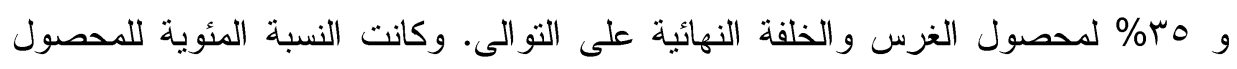

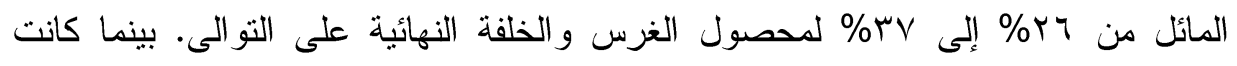

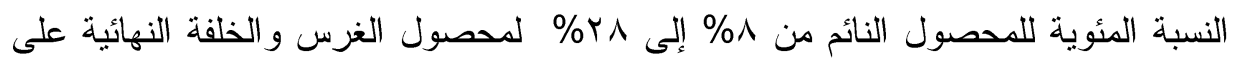

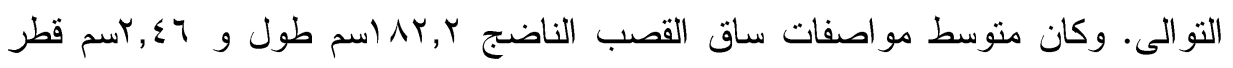


و گrA, •كجم وزن للساق. مع خواص ميكانيكية . .0 نيوتن لقوة القطع لوسط السلامية

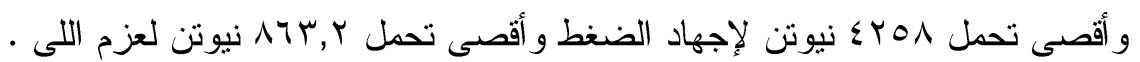
ᄉـ أوضحت نتيائج الدر اسده أن:

- الرقاد وهو أهم الخواص المؤثره على الصاد الميكانيكى تزداد حدته فى التى الخلفات الأقدم حيث زادت نسبة المحصول المائل و الراقد كلما تقدم خلفة القصب فى العمر • ويؤثز الرقاد تأثير اسلبيا كبير ا على الحصاد الميكانيكى .

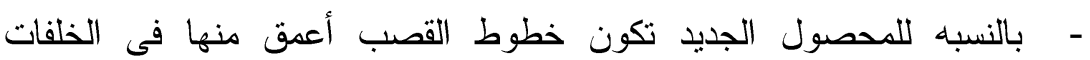
المتتابعه ـ وتأثير عمق الخطوط السلبى على الحصاد الميكانيكى يكون أقل الن

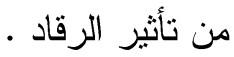

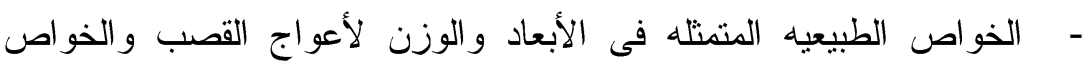
الميكانيكيه المتمثله فى صلابة العود و إجهاد الحنى والضغط لم تختلف كثير الماده فيما بين خلفات القصب ويتوقع ألا تؤدى إلى تباين يذكر فى أداء آلات حصاد

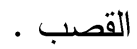
- وعليه فيكون القصب المزروع جديدا و الخلفات الحيثه أكثر تو افقا مع الحصاد

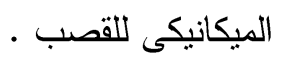

